\title{
Human Plasmodium in Livestock: The Absence of PfHRP2 and $p$ LDH Among High Parasitemia Cases
}

\author{
Didik Sumanto $^{1,2 * \mathbb{D}}$, Suharyo Hadisaputro ${ }^{2}$, Mateus Sakundarno Adi ${ }^{3,4}$, Siti Susanti ${ }^{5}$, Sayono Sayono ${ }^{1}$ \\ ${ }^{1}$ Faculty of Public Health, Universitas Muhammadiyah Semarang, Indonesia \\ ${ }^{2}$ Faculty of Medicine, Universitas Diponegoro Semarang, Indonesia \\ ${ }^{3}$ Faculty of Public Health, Universitas Diponegoro Semarang, Indonesia \\ ${ }^{4}$ Magister of Epidemiology, Universitas Diponegoro Semarang, Indonesia \\ ${ }^{5}$ Faculty of Animal and Agriculture Science, Universitas Diponegoro Semarang, Indonesia
}

\begin{abstract}
Introduction: Plasmodium falciparum and Plasmodium vivax are reported to have infected domestic cattle as buffalo, horses, dogs, and goats in Sumba, along with Etawa crossbreed goats in Purworejo. One of the markers of human-Plasmodium (h-Plasmodium) invasion in the erythrocyte phase is the appearance of $P f H R P 2$ and parasite lactate dehydrogenase (pLDH). This study aimed to detect $h$-Plasmodium using PfHRP2-pLDH-based rapid diagnostic test (RDT) in the blood of Etawa crossbreed goats that were tested positive for microscopic infection.

Methods: A cross-sectional study was conducted in a malaria pre-elimination area in Purworejo District, Indonesia. Livestock blood sampling was performed on a population of goats within a radius of 300 meters from the residence of malaria cases.

Results: The presence of $h$-Plasmodium was detected by Rapid Diagnostic Test (RDT) Monotes Malaria for PfHRP2-pLDH. The mean parasitemia level of $h$-Plasmodium on Etawa crossbreed goats was 3061 parasites $/ \mu \mathrm{L}$ of blood. No cases were detected positive using RDT Monotes Malaria from four goats that were microscopically positive for $h$-Plasmodium.

Conclusion: The PfHRP and pLDH-based RDT methods for the detection of $h$-Plasmodium indicated that they are not sensitive to be applied to animal blood. Other immunological detection methods are needed to determine the activity of $h$-Plasmodium when it invades animal red blood cells.

Keywords: Human-Plasmodium, RDT-malaria, Etawa crossbreed goat
\end{abstract}

Received: March 1, 2021, Accepted: March 5, 2021, ePublished: April 1, 2021

\section{Introduction}

Human-Plasmodium ( $h$-Plasmodium) was found in the blood of Etawa crossbreeds in malaria-endemic areas (1). The cycle of malaria transmission not only does not involve interactions between infectious vectors and humans but also animals. The population density of zoophilic Anopheles has the opportunity to bite and hence inject $h$-Plasmodium to animal blood. The presence of $h$-Plasmodium in the blood of vertebrates cannot be separated from the role of the Anopheles vector that carries it (2). The presence of goats as a source of blood feed will attract female zoophilic Anopheles (3). The bite of infectious Anopheles (4) causes the transfer of sporozoites from mosquitoes to the livestock $(2,5)$, including goats (6). Zoophilic Anopheles maculatus was reported to dominate and was confirmed as a malaria vector (3,7-10). An abundance of blood feed sources will accelerate the gonotrophic cycle of the mosquitoes (11).

Invasion of $h$-Plasmodium into the body of livestock (4) will stimulate an immune response (12) from the intra-hepatic phase $(13,14)$ to the erythrocytic phase
(15-21). The signs of the presence of $h$-Plasmodium in the intrahepatic phase are the appearance of liverstage antigen (13) and an increase in the hormone growth factor (14), while in the erythrocytic phase, it is marked by merozoite surface protein-1 (15), histidinerich protein-2 (HRP-2) (16-18), and parasite lactate dehydrogenase (pLDH) (19-21). PfHRP-2 is expressed by both positive and negative poles of infected erythrocytes, containing $35 \%$ histidine, $40 \%$ alanine, and $12 \%$ aspartate (22). PfHRP-2 begins to be produced when merozoites invade erythrocytes and become a ring-shaped young trophozoite stage (23), but is more dominantly produced by the mature stage of Plasmodium (24). PfHRP-2 is also detected in the developmental stage of Plasmodium falciparum gametocytes in erythrocytes and is a marker of its presence. This protein is expressed from the membrane and cytosol of $P$. falciparum-infected erythrocytes (25).

The parasite synthesizes lactate dehydrogenase in the blood as a terminal enzyme in the glycolytic pathway at the developmental stage. Epitope and characteristics of protein distinguish pLDH enzymes produced by Plasmodium and 
humans physiologically $(19,20)$. The produced enzymes by these four $h$-Plasmodium species (26) catalyze pyruvate to lactate to produce energy to support parasite survival through hematin polymerization (27). pLDH activity can be detected at the level of parasitemia $0.2-10 \%(28,29)$, but it will quickly disappear within three to five days (30).

The blood microscopic examination as the gold standard of malaria detection in humans can also detect the presence of $h$-Plasmodium in animal blood. ${ }^{1}$ The biological activity of the $h$-Plasmodium invasion in the animal's blood needs to be further investigated by examining PfHRP2 (17) and pLDH (21). The implementation of this method is a strategic effort to uncover the complete transmission cycle of the parasite in malaria-endemic areas. The appearance of the two types of protein can reveal the survival of $h$-Plasmodium and a sign of the presence of parasites in the reservoir. This survey aimed to determine the presence of PfHRP2 and pLDH as the markers of $h$-Plasmodium invasion in the blood of Etawa crossbreed goats in a malaria-endemic area in Kaligesing District, Purworejo Regency having the highest number of cases in Central Java Province, Indonesia $(31,32)$.

The purpose of this research is helpful and a basis for using rapid malaria tests on the market to screen livestock around human life. The expansion of malaria screening in livestock is significant because zoophilic Anopheles prefer animal blood. The basic principle of the working mechanism of the rapid malaria test kit is to detect the presence of HRP2 and pLDH enzymes, which are produced by $h$-Plasmodium invading red blood cells. The appearance of HRP2 and pLDH indicated the viability of h-Plasmodium in livestock. Their absence implies significant information and strengthens the hypothesis about the applied livestock as the barrier of society from the bite of Anopheles.

\section{Materials and Methods Study Design and Site}

This cross-sectional study was performed in a malaria pre-elimination area in Jatirejo village, Purworejo district, the central part of Jawa province, Indonesia. The village is the highest area in the Kaligesing sub-district (33). The topography of the hilly areas does not allow residents to have farm activities (34). This condition is empowered by making it a center for the development of Etawa Peranakan goats (33). This region is in Menoreh hills with a natural forest and plantations wider than those of the residential house areas (35). The natural conditions are highly suitable for breeding Anopheles mosquitoes as the vectors of malaria (7). More livestock population from the resident (33) has a potential acceleration of the Anopheles gonotrophic cycle. It becomes a source of blood feed for female zoophilic Anopheles (8). The provincial API value is relatively low (36), but this area has long been endemic for malaria $(37,38)$. Until 2018, new cases of malaria were still found (38) and until the third quarter of 2020, there were still reports of imported cases (39). Another outbreak of malaria appeared in the sub-district adjacent to the previous case in June 2021 (40).

\section{Sample Size and Sampling Technique}

The subjects of the study were Etawa crossbreed goats located within a radius of 300-meter from the residential house of malaria sufferers. The goat's age was at least 3 months or was kept at the location for at least 3 months. The population of Etawa crossbreed was 97 goats, and all of them met the inclusion criteria thus the sample was taken by total sampling.

\section{Blood Collection}

Goat blood specimens were taken by the village malaria interpreter from the capillary blood of the goat's earlobe using a sterile blood lancet aseptically. The target earlobe area was cleaned with an alcohol swab and allowed to dry, and a sterile blood lancet was stabbed into the disinfected area. The first drop of blood was discarded and then the next drop was used for testing.

\section{Rapid Diagnostic Test Monotes Malaria}

A field rapid malaria test was performed on goat blood. The examination was tested by rapid diagnostic test (RDT) Monotes malaria. The RDT was conducted after microscopic examination. Both positive and negative $h$-Plasmodium samples in the microscopic examination (41-44) were tested by RDT. RDT Monotes malaria was used to detect the presence of PfHRP2 and $\mathrm{pLDH}$ in the blood. The blood sample was dripped into the sample hole on the test kit, and then a buffer kit solution was added and remained for 15 minutes. The addition of a buffer solution for the dilution of the sample can be more easily absorbed by semi-permeable media to reach the antigen point. The PfHRP2 and pLDH proteins in the blood sample will bind to the malaria antigen and be detected by the formation of a red line on the device. The sensitivity and specificity were $90 \%$ and $100 \%$, respectively. This accuracy in blood samples was with a minimum parasitemia level of $40 / \mathrm{uL}$ (45).

\section{Parasitemia Level}

It was computed as h-Plasmodium positive on a thick blood slide. The calculation method uses the CDC approach based on the ratio of the number of parasites to white blood cells (WBCs). The estimated average WBC per microliter is 8000 cells. The average number of parasites found per converted visual field is proportional to the number of $8000 \mathrm{WBCs}$ in the entire observational field. The calculation results are in units of the number of parasites per $8000 \mathrm{WBCs}$ or proportional to the number of parasites per microliter of blood (parasites $/ \mu \mathrm{L}$ of blood) 
according to previous research (46).

\section{Results}

Of the 97 examined goats, only four cases were microscopically detected for the presence of the $h$-Plasmodium parasite in the blood samples. All the observed h-Plasmodium parasites in the blood of Etawa crossbreed goats were in the trophozoite stage, both early and late stages. Parasite density was relatively high and varied in four positive Etawa crossbreed goats for h-Plasmodium at the survey location (Figure 1).

Parasite findings were found in $200 \mathrm{WBCs}$ and converted to microliter units of the blood sample. Conversion calculations were based on CDC estimation standards (46). The results of microscopic and rapid test techniques are presented as is because the data are categorical. The microscopic tests were confirmed by the specific morphology of the parasites. There was no further statistical analysis on these data because the purpose of data collection was to reveal the presence of the $h$-Plasmodium parasite and its activity marker in the form of HRP2-pLDH.

The parasite density was relatively high, ranging from 1000 to 5000 per microliter of livestock blood (Table 1).

All the microscopically examined blood specimens were then tested using RDT Monotes Malaria. None of the goat blood samples showed positive results on the RDT Monotes Malaria test, including the goat blood sample which was detected positive based on microscopic examination (Table 2).

\section{Discussion}

The discovery of $P$. falciparum and $P$. vivax trophozoites in the blood of goats and the level of parasitemia calculating are new steps in malaria research and have rarely been reported by previous studies. The current
Table 1. Parasite Density in Goat Blood

\begin{tabular}{|c|c|c|c|}
\hline \multirow[b]{2}{*}{ Figure } & \multirow[b]{2}{*}{ Species and Stage } & \multicolumn{2}{|c|}{ Parasite Density } \\
\hline & & $\begin{array}{l}\text { Parasite/200 } \\
\text { leukocyte }\end{array}$ & Parasite/ $\mu \mathrm{L}$ \\
\hline 1.1 & Plasmodium vivax, trophozoite & 33 & 1.333 \\
\hline 1.2 & Plasmodium falciparum, trophozoite & 133 & 5.333 \\
\hline 1.3 & Plasmodium falciparum, trophozoite & 73 & 2.909 \\
\hline 1.4 & Plasmodium falciparum, trophozoite & 67 & 2.667 \\
\hline
\end{tabular}

Table 2. RDT Monotes Malaria Detection on Microscopic Positive Samples

\begin{tabular}{lrl}
\hline Sample & Microscopic Detection & Monotes Malaria (RDT) \\
\hline 1 & Plasmodium vivax, trophozoite & Negative \\
2 & Plasmodium falciparum, trophozoite & Negative \\
3 & Plasmodium falciparum, trophozoite & Negative \\
4 & Plasmodium falciparum, trophozoite & Negative \\
\hline Note. RDT: Rapid diagnostic test.
\end{tabular}

study is a continuation of the findings of h-Plasmodium on previous Etawa goats (1) as an effort to reveal the impasse of information on the role of livestock as hosts for $h$-Plasmodium. The findings of similar parasites were also reported in livestock populations in Sumba (47). The detected malaria parasites in the trophozoite stage indicated that h-Plasmodium transmission occurred in mammalian livestock groups other than humans. The trophozoite stage, both young and old, was found to represent the ability of this parasite to survive to reach the erythrocytic phase. This erythrocyte phase is important because the final stage, gametocytes (48), will be an indication of whether the animal species is a reservoir of the disease or not.

The findings of h-Plasmodium in livestock have opened new horizons in controlling malaria. Studies on malaria control using livestock have only been limited to epidemiological studies, presenting highly varied and

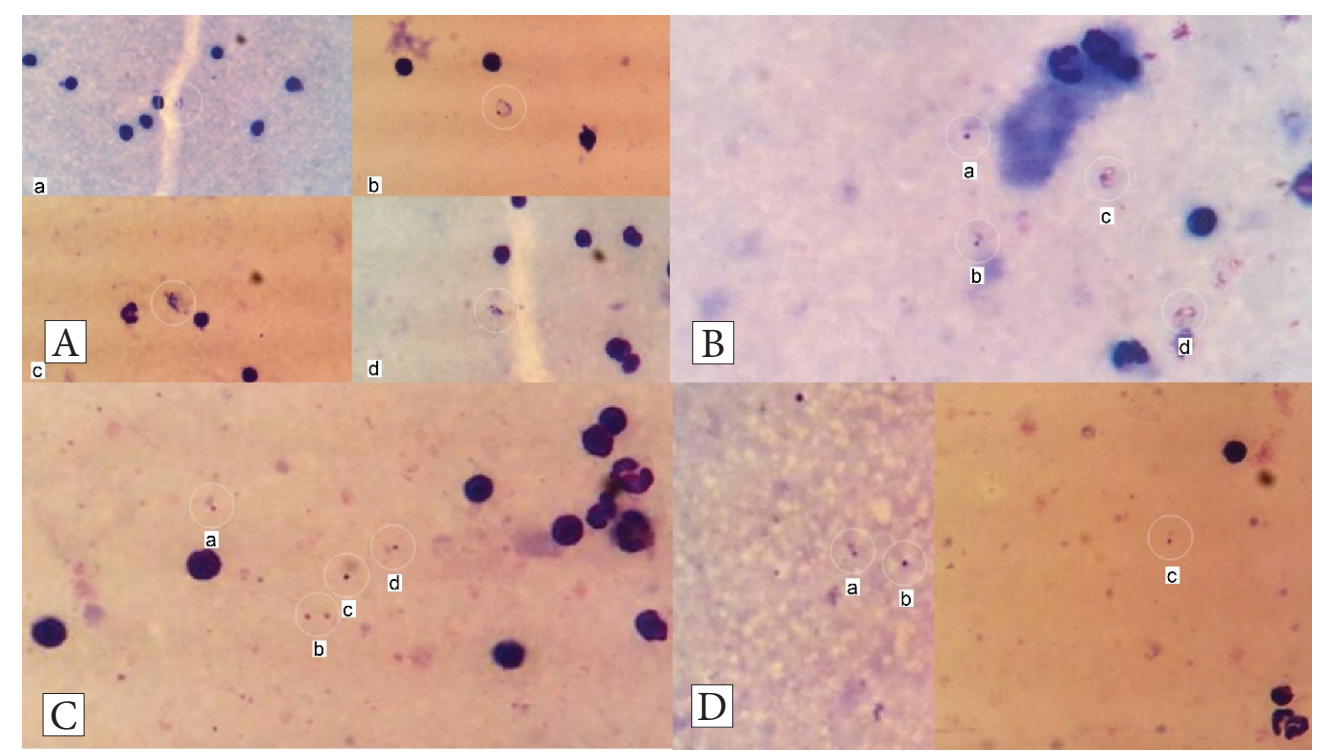

Figure 1. Parasite Density Under Microscopic Observation (10 x 100). 
even contradictory results. The findings of $h$-Plasmodium in primates have long been reported (49), but those related to domestic livestock are considered a novelty.

This finding becomes extremely important to malaria control by cattle barriers. Furthermore, if the only trophozoite stage findings assumed the parasite is no longer growing, the estimation of transmission from zoophilic Anopheles vectors to livestock occurs within the last few days. This means that it is still highly possible to have an infective Anopheles vector at the survey site, thus it is important to perform vector control efforts.

Many people still question the transmission ability of h-Plasmodium in livestock, but the morphological characteristics of the findings show an undeniable argument. Infection with a parasitemia level of 1.333/ $\mu \mathrm{L}$ demonstrated the presence of trophozoites in several early and late phases where the ring-shaped nucleus and cytoplasm of the parasite were visible (a) and the developed trophozoites had a clearer cytoplasmic ring (b), while the amoeboid cytoplasm was typical of the species. It is equipped with a reddish core $(c, d)$. The morphological characteristics of this finding are in close agreement with those of the trophozoites of $P$. vivax (48,50-52), thus they are extremely convincing. As depicted in Figure 1A, the morphology of the advanced trophozoites is highly clear with a reddish round nucleus, while the cytoplasm of the parasite is thick and amoeboid by the released characteristics of CDC (53).

The second slide with a parasitemia level of $5333 / \mu \mathrm{L}$ represents the young trophozoite stage of $P$. falciparum. A round nucleus with a thin crescent-like cytoplasm (a, b) appears, while 2 parasites with overlapping nuclei (c) characterizing the form of multiple infections (54) and one parasite with a reddish-colored nucleus cytoplasm with a distinctive smooth ring shape (d) are observed in the advanced stage (Figure 1B). The third slide with a parasitemia level of $2909 / \mu \mathrm{L}$ demonstrates $P$. falciparum trophozoites at an early stage where the nucleus was round without (b) or with thin cytoplasm that was similar to a coma-like tinge (a, c, d, Figure $1 \mathrm{C}$ ). The fourth slide depicts a parasitemia level of $2667 / \mu \mathrm{L}$ of trophozoite $P$. falciparum findings. In the earliest stage, a round-shape nucleus was found with extremely thin and even barely visible cytoplasm (b), whereas parasites with an advanced age began to have cytoplasmic tinges, even though only a thin line was visible (a, c, Figure 1D) The overall morphology of the young trophozoite stage $P$. falciparum was found to have a characteristic reddish core of the cytoplasm in the form of a fine ring (55). The distinctive shape of the ring at this stage has many variations, one of which is only point-shaped, the parasite nucleus is reddish, while the cytoplasm is still extremely thin and may not even be visible (56). The maturation process is indicated by the completeness of the cytoplasm as a ring. In the initial phase, the ring shape often looks imperfect thus it can be detected as a comma, exclamation mark, or maybe something that resembles a flying bird (50).

By the information of the procedure manual on the applied product, the Monotes Malaria rapid detection tool has a specificity level of $100 \%$ and a sensitivity rate of $90 \%$ in samples with a parasitemia degree of at least 40 parasites/ $\mu \mathrm{L}$ (45). It implies that if the sample under examination has a parasitemia degree of less than this number, the tool is unable to read the enzymes formed by the parasite. RDT Monotes Malaria was produced with the principle of detecting the presence of PfHRP2 and $\mathrm{pLDH}$ (45). The reliability of this product has been proven by the Meninting Health Center of West Nusa Tenggara Province, where the results are superior to microscopic examinations (57).

The presence of the trophozoite stage should be supported by the appearance of specific proteins from h-Plasmodium, namely, PfHRP2 (58) and pLDH $(17,21)$. Theoretically, PfHRP2 will appear within 3 days of merozoites starting to invade red blood cells (60) and will continue to form while the parasite is still in the red blood cells until the gametocyte stage (25). Detection using RDT Monotes Malaria for goat blood in this study showed negative results despite finding the morphology of $h$-Plasmodium microscopically. Based on the number of observed parasites in the blood sample, this tool should be able to detect the presence of PfHRP2 and pLDH considering that the number of parasites in the blood is more than 40 parasites/ $\mu \mathrm{L}$. The presence of a trophozoite stage not followed by the appearance of PfHRP2 in the goat blood is an interesting issue that needs further investigation. Most of the found $P$. falciparum stages were early trophozoites. Undetected PfHRP2 is very likely to have a low concentration due to the absence of a significant amount of parasitic proteins (23) because the formation of PfHRP2 is more dominant in the mature trophozoite phase (24), although it will continue to be formed until the gametocyte stage (25). This suggests that PfHRP2 will continue to be formed during the erythrocytic phase in the schizogony cycle.

Similarly, the pLDH enzyme was not detected from all microscopic positive samples. The number of detected parasites in the range of 1000-5000 per microliter of blood should be sufficient for producing $\mathrm{pLDH}$. According to reports on human subjects, pLDH activity can be easily detected in blood samples with parasitemia levels of 0.2 $10 \%$ against erythrocytes $(28,29)$, which is comparable to the range of 125-6250 parasites per microliter of blood. The pLDH enzyme only survives for a few days after the parasite dies (30), but the fact is that the parasite is still found in relatively high numbers and can be detected microscopically.

RDT Monotes Malaria is designed for examination with human blood specimens (45), therefore, it is necessary to check for the application to animal blood because it is very 
likely to have some differences in the composition of blood cells, viscosity, and the mechanism of antibody formation. Although the findings of this study have not provided a final answer, information gaps have been found that are increasingly interesting for further investigation. Some questions remain whether it is true that RDT Monotes Malaria cannot detect parasites in non-human blood cells or there is a highly different immune system mechanism in goat blood causing $h$-Plasmodium to be unable to produce PfHRP2 and pLDH. Further studies must be conducted to find answers to some of these new axioms, and this challenge is of great interest to researchers.

\section{Conclusion}

The absence of PfHRP2 and pLDH does not mean the lack of their physiological formation. It is highly recommended that testing with the best methods and detection tools be considered to obtain the best results, especially for the early trophozoite phase.

\section{Recommendations}

Of the 97 investigated goats, only four cases were microscopically detected for the presence of the h-Plasmodium parasite in the blood. In other words, only four blood samples had the potential to contain HRP2-pLDH. A similar study should be conducted with a high endemic location and a sufficient number of $h$-Plasmodium positive livestock blood samples to compare the results. Moreover, an in vivo study can be performed to further assess the viability of $h$-Plasmodium in livestock blood and more deeply delve into its life in the body of livestock and animals that are potential reservoirs.

\section{Acknowledgment}

We would like to thank all the staff of the Kaligesing Health Center who assisted in conducting the field survey.

\section{Authors' Contribution}

DS collected data, and then wrote and edited the manuscript, $\mathrm{SH}$, MSA, and SS designed the study, and SY analyzed the obtained data.

\section{Conflict of Interests}

The authors declare that they have no conflict of interests.

\section{Ethical Issues}

The ethical approval (number 029/EC/FK/2020) was obtained from the Health Research Ethics Committee, Faculty of Medicine, Universitas Muhammadiyah Semarang.

\section{Funding}

The authors received no financial support for the research, authorship, and publication of this article.

\section{References}

1. Sumanto D, Hadisaputro S, Adi MS, Susanti S, Sayono S. Parasit Plasmodium sp pada Ternak Kambing Etawa di Daerah Endemik Malaria Kabupaten Purworejo. J Ekol Kesehat. 2021;20(1):36-44. doi:10.22435/jek.v20i1.4092

2. Mayagaya VS, Nkwengulila G, Lyimo IN, et al. The impact of livestock on the abundance, resting behaviour and sporozoite rate of malaria vectors in southern Tanzania. Malar J. $2015 ; 14: 17$. doi:10.1186/s12936-014-0536-8
3. Putranto NT, Handoyo W, Sumanto D. Keragaman dan Kepadatan Vektor Anopheles sp di Jatirejo Purworejo. J Kesehat Masy Indones. 2020;15(2):39-41. doi:10.26714/ jkmi.15.2.2020.39-41

4. CDC. Live cycle of Plasmodium spp. 2017. Available from: http://www.dpd.cdc.gov/dpdx.

5. Thomas S, Ravishankaran S, Justin NA, et al. Resting and feeding preferences of Anopheles stephensi in an urban setting, perennial for malaria. Malar J. 2017;16(1):111. doi:10.1186/s12936-017-1764-5

6. Waite JL, Swain S, Lynch PA, et al. Increasing the potential for malaria elimination by targeting zoophilic vectors. Sci Rep. 2017;7:40551. doi:10.1038/srep40551

7. Lestari EW, Sukowati S, Soekidjo S, Wigati RA. Vektor Malaria di Daerah Bukit Menoreh, Purworejo, Jawa Tengah. Media Litbang Kesehat. 2007;17(1):30-35.

8. Sugiarto, Hadi UK, Soviana S, Hakim L. Bionomics of Anopheles (Diptera: Culicidae) in a malaria endemic region of Sungai Nyamuk village, Sebatik Island - North Kalimantan, Indonesia. Acta Trop. 2017;171:30-36. doi:10.1016/j. actatropica.2017.03.014

9. Kirnowardoyo S. Status of Anopheles malaria vectors in Indonesia. Southeast Asian J Trop Med Public Health. 1985;16(1):129-132.

10. Franco AO, Gomes MG, Rowland M, Coleman PG, Davies CR. Controlling malaria using livestock-based interventions: a one health approach. PLoS One. 2014;9(7):e101699. doi:10.1371/journal.pone.0101699

11. Lobo V, Laumalay HM. Studi Laboratorium Siklus Hidup Anopheles vagus Pradewasa sebagai Vektor Filariasis dan Malaria di Provinsi Nusa Tenggara Timur. Balaba J Litbang Pengendali Penyakit Bersumber Binatang Banjarnegara. 2019;15(1):61-68. doi:10.22435/blb.v15i1.924

12. Klotz C, Frevert U. Plasmodium yoelii sporozoites modulate cytokine profile and induce apoptosis in murine Kupffer cells. Int J Parasitol. 2008;38(14):1639-1650. doi:10.1016/j. ijpara.2008.05.018

13. Hillier CJ, Ware LA, Barbosa A, et al. Process development and analysis of liver-stage antigen 1, a preerythrocyte-stage protein-based vaccine for Plasmodium falciparum. Infect Immun. 2005;73(4):2109-2115. doi:10.1128/iai.73.4.21092115.2005

14. Nakamura T, Mizuno S. The discovery of hepatocyte growth factor (HGF) and its significance for cell biology, life sciences and clinical medicine. Proc Jpn Acad Ser B Phys Biol Sci. 2010;86(6):588-610. doi:10.2183/pjab.86.588

15. Kadekoppala M, Holder AA. Merozoite surface proteins of the malaria parasite: the MSP1 complex and the MSP7 family. Int J Parasitol. 2010;40(10):1155-1161. doi:10.1016/j. ijpara.2010.04.008

16. Aley SB, Sherwood JA, Howard RJ. Knob-positive and knob-negative Plasmodium falciparum differ in expression of a strain-specific malarial antigen on the surface of infected erythrocytes. J Exp Med. 1984;160(5):1585-1590. doi:10.1084/jem.160.5.1585

17. Poti KE, Sullivan DJ, Dondorp AM, Woodrow CJ. HRP2: transforming malaria diagnosis, but with caveats. Trends Parasitol. 2020;36(2):112-126. doi:10.1016/j.pt.2019.12.004

18. Plucinski MM, Dimbu PR, Fortes $F$, et al. Posttreatment HRP2 clearance in patients with uncomplicated Plasmodium falciparum malaria. J Infect Dis. 2018;217(5):685-692. doi:10.1093/infdis/jix622

19. Vander Jagt DL, Hunsaker LA, Heidrich JE. Partial purification and characterization of lactate dehydrogenase from Plasmodium falciparum. Mol Biochem Parasitol. 1981;4(56):255-264. doi:10.1016/0166-6851(81)90058-x 
20. Makler MT, Piper RC, Milhous WK. Lactate dehydrogenase and the diagnosis of malaria. Parasitol Today. 1998;14(9):376377. doi:10.1016/s0169-4758(98)01284-8

21. Hemben A, Ashley J, Tothill IE. An immunosensor for parasite lactate dehydrogenase detection as a malaria biomarker comparison with commercial test kit. Talanta. 2018;187:321329. doi:10.1016/j.talanta.2018.04.086

22. Wellems TE, Howard RJ. Homologous genes encode two distinct histidine-rich proteins in a cloned isolate of Plasmodium falciparum. Proc Natl Acad Sci U S A. 1986;83(16):6065-6069. doi:10.1073/pnas.83.16.6065

23. Howard RJ, Uni S, Aikawa M, et al. Secretion of a malarial histidine-rich protein (Pf HRP II) from Plasmodium falciparuminfected erythrocytes. J Cell Biol. 1986;103(4):1269-1277. doi:10.1083/jcb.103.4.1269

24. Dondorp AM, Desakorn V, Pongtavornpinyo W, et al. Estimation of the total parasite biomass in acute falciparum malaria from plasma PfHRP2. PLoS Med. 2005;2(8):e204. doi:10.1371/journal.pmed.0020204

25. Ndour PA, Larréché S, Mouri O, et al. Measuring the Plasmodium falciparum HRP2 protein in blood from artesunate-treated malaria patients predicts post-artesunate delayed hemolysis. Sci TransI Med. 2017;9(397). doi:10.1126/ scitranslmed.aaf9377

26. Baker J, McCarthy J, Gatton M, et al. Genetic diversity of Plasmodium falciparum histidine-rich protein 2 (PfHRP2) and its effect on the performance of PfHRP2-based rapid diagnostic tests. J Infect Dis. 2005;192(5):870-877. doi:10.1086/432010

27. Egan TJ, Ncokazi KK. Quinoline antimalarials decrease the rate of beta-hematin formation. J Inorg Biochem. 2005;99(7):1532-1539. doi:10.1016/j.jinorgbio.2005.04.013

28. Makler MT, Ries JM, Williams JA, et al. Parasite lactate dehydrogenase as an assay for Plasmodium falciparum drug sensitivity. Am J Trop Med Hyg. 1993;48(6):739-741. doi:10.4269/ajtmh.1993.48.739

29. Oduola AM, Omitowoju GO, Sowunmi A, et al. Plasmodium falciparum: evaluation of lactate dehydrogenase in monitoring therapeutic responses to standard antimalarial drugs in Nigeria. Exp Parasitol. 1997;87(3):283-289. doi:10.1006/ expr.1997.4251

30. Piper R, Lebras J, Wentworth L, et al. Immunocapture diagnostic assays for malaria using Plasmodium lactate dehydrogenase (pLDH). Am J Trop Med Hyg. 1999;60(1):109118. doi:10.4269/ajtmh.1999.60.109

31. Kuswantoro K. Profil Kesehatan Dinas Kesehatan Kabupaten Purworejo 2015. Purworejo; 2015:22. Available from: www. depkes.go.id/.../profil/PROFIL_KAB.../3306_Jateng_Kab_ Purworejo_2014.pdf.

32. Prabowo Y. Profil Kesehatan Provinsi Jawa Tengah Tahun 2016 [Internet]. Dinas Kesehatan Prov. Jateng. Semarang; 2016. p. 36. Available from: http://dinkesjatengprov.go.id/v2018/ dokumen/profil2016/mobile/index.html\#p=1

33. Susanto RBR. Kecamatan Kaligesing Dalam Angka 2019. Purworejo: BPS Kabupaten Purworejo; 2019:10. Available from: https://purworejokab.bps.go.id/ publication/2019/09/26/7407bd574a4e17c16d63792c/ kecamatan-kaligesing-dalam-angka-2019.html.

34. Wazzirudin W. Kecamatan Kaligesing Dalam Angka 2017. Purworejo: BPS Kabupaten Purworejo; 2017:51. Available from: https://purworejokab.bps.go.id/ publication/2017/09/19/711515a83440b6a9634c4d03/ kecamatan-kaligesing-dalam-angka-2017.html.

35. Wazzirudin W. Kecamatan Kaligesing Dalam Angka 2018. Purworejo: BPS Kabupaten Purworejo; 2018:45-49. Available from: https://purworejokab.bps.go.id/publication/2018/09/26/ a88a2a204be1b0201632e600/kecamatan-kaligesing-dalam- angka-2018.html.

36. Profil Kesehatan Provinsi Jawa Tengah Tahun 2019. Semarang: Dinas Kesehatan Provinsi Jawa Tengah; 2020:105. Available from: http://dinkesjatengprov.go.id/v2018/dokumen/ profil2019/mobile/index.html\#p=118.

37. Setyorini A. Kejadian Malaria di Kaligesing Tahun 2016. Purworejo: Puskesmas Kaligesing; 2016:7-10.

38. Bayu B. Data Kejadian Malaria Kecamatan Kaligesing Tahun 2018. Purworejo; 2018:10-15.

39. Wibowo MA. Buku Saku Kesehatan Triwulan 3 Tahun 2020. Semarang: Dinas Kesehatan Provinsi Jawa Tengah; 2020:4244.

40. Prabowo Y. Buku Saku Kesehatan Tahun 2021 Triwulan 2. Semarang: Dinas Kesehatan Provinsi Jawa Tengah; 2021:43. Available from: https://dinkesjatengprov.go.id/v2018/ storage/2021/08/1_Buku_Saku_Kes_tw2_2021_Final-1.pdf.

41. World Health Organization (WHO). Malaria Microscopy Quality Assurance Manual. 2nd ed. Geneva: WHO; 2016:140. Available from: https://www.who.int/docs/defaultsource/documents/publications/gmp/malaria-microscopyquality-assurance-manual.pdf?sfvrsn=dfe54d47_2.

42. U.S. Department of Health \& Human Service. Malaria Diagnosis. cdc.gov. 2015. Available from: https://www.cdc. gov/malaria/diagnosis_treatment/diagnosis.html.

43. Centers for Disease Control and Prevention (CDC). Laboratorium Diagnosis of Plasmodium vivax. CDC; 2017:1-4. Available from: https://www.cdc. govdpdxresourcespdfbenchAidsmalariaPvivax_benchaidV2. pdf.

44. U.S. Department of Health \& Human Service. Malaria Parasites. www.cdc.gov. 2016. Available from: https://www. cdc.gov/malaria/about/biology/parasites.html.

45. Jimenez A, Rees-Channer RR, Perera R, Gamboa D, Chiodini PL, González IJ, et al. Analytical sensitivity of current best-inclass malaria rapid diagnostic tests. Malar J. 2017;16(1):1-9. doi: 10.1186/s12936-017-1780-5

46. Centers for Disease Control and Prevention (CDC). DPDx - Laboratory Identification of Parasites of Public Health Concern. CDC; 2016:5-6. Available from: https://www.cdc. gov/dpdx/diagnosticprocedures/stool/specimenproc.html. Accessed July 25, 2021.

47. Munirah M, Wahyuni S, Wahid I, Hamid F. Human Plasmodium in domestic animals in West Sumba and Fakfak, Indonesia [Preprint]. Res Sq. 2020. doi:10.21203/rs.3.rs-98594/v1

48. Mahmud R, Lim YA, Amir A. Medical Parasitology. Cham, Switzerland: Springer International Publishing; 2017:40. doi:10.1007/978-3-319-68795-7

49. Araújo MS, Messias MR, Figueiró MR, et al. Natural Plasmodium infection in monkeys in the state of Rondônia (Brazilian Western Amazon). Malar J. 2013;12:180. doi:10.1186/1475-2875-12-180

50. Chiodini P, Moody A, Manser D. Atlas of Medical Helminthology and Protozoology. 4th ed. London: Churchill Livingstone; 2001:61-69.

51. Melvin M. Photomicrograph of the malaria causing parasite Plasmodium vivax, in ring and young trophozoite forms, on a thick film blood smear with Giemsa stain. Alamy's library from CDC. 1971. Available from: https://www.alamy.com/ stock-photo-photomicrograph-of-the-malaria-causingparasite-plasmodium-vivax-in-173101553.html. Accessed August 19, 2019.

52. Keas BE. Microscopy - Plasmodium species. msu.edu. 1999. Available from: https://msu.edu/course/zol/316/psppscope. htm.

53. CDC. Ring-form trophozoites of $P$. vivax in thick and thin blood smears. U.S. Department of Health \& Human Services. 
2017. Available from: https://www.cdc.gov/dpdx/malaria/ index.html. Accessed August 19, 2019.

54. Haind Fadel MD. Microbiology \& Parasitology. PathologyOutlines.com, Inc; 2021:1-4. Available from: https://www.pathologyoutlines.com/topic/ parasitologymalariapfalciparum.html. Accessed August 6, 2021.

55. MCD International. Plasmodium falciparum: Ring form trophozoites in thick blood smears (Image Library Malaria). mcdinternational.org. 2009. Available from: https:// mcdinternational.org/trainings/malaria/english/dpdx5/ html/ImageLibrary/M-R/Malaria/falciparum/body_Malaria_ falciparum_il4. Accessed August 17,2019.

56. Bannister LH, Hopkins JM, Fowler RE, Krishna S, Mitchell $\mathrm{GH}$. A brief illustrated guide to the ultrastructure of
Plasmodium falciparum asexual blood stages. Parasitol Today. 2000;16(10):427-433. doi:10.1016/s0169-4758(00)01755-5

57. Ayuningsih RA, Halid I, Ustiawaty J. Perbandingan Hasil Diagnosa Malaria Metode RDT Dengan Mikroskopis di Puskesmas Meninting NTB. Media Med Lab Sci. 2018;2(2):8996.

58. Plucinski MM, Dimbu PR, Fortes F, et al. Posttreatment HRP2 clearance in patients with uncomplicated Plasmodium falciparum malaria. J Infect Dis. 2018;217(5):685-692. doi:10.1093/infdis/jix622

59. Garedaghi Y, Khaki A. Evaluation of the effectiveness of ethanolic extract of Solanum surattense against Plasmodium berghei in comparison with choloroquine in Sourian mice using in vivo tests. Med J Tabriz Univ Med Sci Health Serv. 2016;37(6):40-45. [Persian].

(C) 2021 The Author(s); This is an open-access article distributed under the terms of the Creative Commons Attribution License (http:// creativecommons.org/licenses/by/4.0), which permits unrestricted use, distribution, and reproduction in any medium, provided the original work is properly cited. 